\title{
Comparison of petroleum biodegradation efficiencies of three different bacterial consortia determined in petroleum-contaminated waste mud pit
}

\author{
Sezen Bilen Ozyurek ${ }^{1}$ [D Isil Seyis Bilkay ${ }^{1}$
}

Received: 29 July 2019 / Accepted: 15 January 2020 / Published online: 25 January 2020

(c) Springer Nature Switzerland AG 2020

\begin{abstract}
The objectives of this study were to determine and compare the petroleum biodegradation efficiencies of three different bacterial consortia adapted to oil field. For this purpose, petroleum-contaminated waste mud sample was enriched in Bushnell Haas medium with 1\% petroleum. Six different bacterial strains (four Gram-positive and two Gram-negative) were isolated from the enriched sample, and bacterial strains were identified with phenotypic and genotypic analyses. Each bacterial strain was evaluated in terms of biodegradation capacities by colorimetric analysis with the DCPIP redox indicator. Petroleum biodegradation efficiencies of three different consortia were investigated by gravimetric and GC-MS analyses. Consortium 1, consisting of Bacillus subtilis, Leuconostoc mesenteroides, Bacillus halotolerans, Enterococcus casseliflavus; consortium 2, consisting of Klebsiella pneumoniae and Pannonibacter phragmitetus; consortium 3, consisting of Bacillus subtilis, Leuconostoc mesenteroides, Bacillus halotolerans, Enterococcus casseliflavus, Klebsiella pneumoniae and Pannonibacter phragmitetus, were used in petroleum biodegradation. According to the results of gravimetric analysis, biodegradation of petroleum was $48 \%, 77 \%$ and $82 \%$ for consortium 1, consortium 2 and consortium 3, respectively. The results of GC-MS analysis revealed that removal of long-chain $n$-alkanes $\left(C_{23}-C_{32}\right)$ was in the range of 35-58\% by consortium $1 ; 56-67 \%$ by consortium 2; and $63-74 \%$ by consortium 3 . It was emphasized that consortium 2 was more effective in biodegradation of petroleum than consortium 1. This study clearly demonstrated that consortium 3 is most effective in biodegradation of petroleum. This is assumed to be due to the synergistic effect between Gram-positive and Gram-negative bacterial strains. Furthermore, consortium 3 has been found to be very successful despite the shorter incubation period compared to other consortia in the literature. In this context, it is believed that the use of consortium 3 will contribute to the bioremediation of petroleum on a large scale.
\end{abstract}

Keywords Petroleum · Biodegradation · Gram-positive bacteria · Gram-negative bacteria · Bacterial consortium · Waste mud pit

\section{Introduction}

Petroleum hydrocarbons are complex mixtures of alkanes, cycloalkanes, various aromatic hydrocarbons and other organic compounds containing nitrogen $(\mathrm{N})$, sulfur $(\mathrm{S})$, oxygen $(\mathrm{O})$ and positive ions [1]. Petroleum is the most important raw material and energy source of the chemical industry. However, the process of operating, transporting and refining of petroleum can cause environmental pollution on a large scale. Particularly, polycyclic aromatic hydrocarbons (PAHs) have carcinogenic, mutagenic, teratogenic and other toxic properties. High molecular weight PAHs, polycyclic aromatic sulfur heterocycles (PASHs), methyl tertiary butyl ether (MTBE), heavy fuel oil and

Sezen Bilen Ozyurek, sbilen@hacettepe.edu.tr | ${ }^{1}$ Department of Biology (Biotechnology), Faculty of Science, Hacettepe University, Ankara, Turkey. 
other petroleum compounds could be resistant to microbial biodegradation. Therefore, petroleum compounds can cause a widespread environmental pollution in groundwater, atmosphere, terrestrial ecosystem, sea water and sediments. Petroleum-contaminated soil, groundwater and freshwater contain different concentrations of various salts, organics, alcohols, phenols, acids, radionuclides, PAHs, zinc, cadmium, mercury, copper, chromium and lead. This exhibits frequently a serious threat to aquatic life, human health, aquatic ecological resources and systems and leads to deterioration of ecological balance [2-6].

In recent years, intensive studies have been carried out to determine the most effective method for the removal of petroleum pollutants from the environment. Although the removal of petroleum hydrocarbons causing environmental pollution can be carried out by chemical oxidation, photolysis, evaporation, sediment and absorption of soil particles, the most effective methods are thought to be microbial transformation and biodegradation targeting bioremediation. Microbial remediation (bioremediation) is considered to be the most effective and cost-effective method of remediation strategies applied to areas contaminated by petroleum [7, 8]. Bioremediation processes are aimed at microbial catabolic diversity for biodegradation and biotransformation of hydrocarbons, polychlorinated biphenyls (PCBs), PAHs, radionuclides and metals $[9,10]$. Bioremediation can be divided into three stages. The first step is the natural attenuation process in which the pollutant is degraded by the microorganisms in the natural habitat, the second step is biostimulation where nutrients and oxygen are added, and the third step is bioaugmentation (biological enhancement) in which the microorganisms are added $[9,11]$. Compared to physical and chemical methods, biological degradation is a highly effective, economical and environmentally friendly for removing the petroleum pollution [6]. Biodegradation can be defined as the conversion of chemical compounds into energy, mass, $\mathrm{CO}_{2}$ and biological waste through living organisms [12]. Briefly, biodegradation is an important process in which organic compounds are broken down into smaller compounds by living microbial organisms. The process of complete degradation of organic pollutants is called mineralization $[9,13]$. Although different groups of microorganisms are able to detoxify complex organic compounds, it is known that bacteria are more effective in detoxification and biodegradation processes [14]. Bacteria have many advantages such as genetic diversity with horizontal gene transfer, high reproduction rate, metabolic diversity and adaptability to variable environmental conditions. Petroleum containing saturated hydrocarbons, aromatic hydrocarbons and polar compounds at different ratios is biodegraded in different rates by the same microorganism. Microbial degradation with natural populations can be enhanced by bioremediation technologies. The bioremediation process depends on the presence of suitable microorganisms, multiple environmental factors and composition of petroleum $[1,15]$.

In the bioremediation process, mixed cultures compared to pure cultures are more advantageous due to the synergistic interaction between microbial strains. The mechanism of synergistic interaction between microorganisms that plays a role in petroleum biochemistry is quite complex. Any microbial strain in a mixed culture may be able to remove the toxic metabolites resulting from another microbial metabolic activity. Therefore, it is necessary to know the role of each microbial pathway in order to understand the activities of each bacterium in mixed cultures during petroleum biodegradation [16]. There is no identified species with metabolic capacity to biodegrade all the compounds of petroleum at the same time. Biodegradation of petroleum is achieved by the combination of microbial strains with different genetic information $[1,17]$. The wide range of biodegradation of petroleum requires the combination of different bacterial strains with a large enzymatic capacity. Different bacterial strains and bacterial consortia are predominant in biodegradation of petroleum hydrocarbons $[4,8,18]$. Pseudomonas sp., Klebsiella sp., Sphingomonas sp., Moraxella sp., Acinetobacter sp., Alcaligenes sp. and Proteus sp. are among the most common Gram-negative bacterial strains; Bacillus sp., Moraxella sp. and Actinomycetes are among the most common Grampositive bacterial strains $[19,20]$.

In particular, petroleum hydrocarbons can be biodegraded in a shorter time and more effectively by microbial communities that were exposed to petroleum pollution than microbial communities that have not been exposed to pollution [19]. These microbial communities can metabolize various hydrocarbons in petroleum synergistically or independently of each other in the environment [4]. For this purpose, three different bacterial consortia (consortium 1, consortium 2 and consortium 3 ) were composed in order to examine the antagonistic and synergistic effects between Gram-positive and Gram-negative bacterial strains, both, separately and together, in the biodegradation process. In the first step of study, isolation and identification of different bacterial strains that were adapted to petroleum-contaminated waste mud pit and determination of petroleum biodegradation capacities of each isolated bacterial strain by colorimetric analysis were aimed. In the next step, three different bacterial consortia with these bacterial strains were composed and the petroleum biodegradation efficiencies of these bacterial consortia, where Gram-positive and Gram-negative bacterial strains were used separately (consortium 1 and consortium 2) and combined (consortium 3), were detected. Growth intensities and petroleum biodegradation efficiencies of three 
different bacterial consortia were examined by spectrophotometric and gravimetric analyses, respectively. In the last step, GC-MS analysis was performed to determine the biodegradation of $n$-alkanes constituting the content of the petroleum. Thus, the efficiencies of petroleum biodegradation of three different consortia were determined and compared with each other and studies in the literature.

\section{Materials and methods}

\subsection{Sampling}

Petroleum-contaminated waste mud sample, produced during the drilling process, was collected in a sterile bottle from an oil field in Savur, Turkey. The collected sample was transported within $12 \mathrm{~h}$ to Hacettepe University Environmental Biotechnology Laboratory.

\subsection{Enrichment of waste mud sample}

Enrichment of microbial content of the sample was carried out with Bushnell Haas (BH) medium containing petroleum (Diyarbakır, Turkey) as a sole carbon source in aerobic conditions. $\mathrm{BH}$ medium is composed of $0.2 \mathrm{~g} / \mathrm{L} \mathrm{MgSO}_{4}$ $0.02 \mathrm{~g} / \mathrm{L} \mathrm{CaCl}, 1 \mathrm{~g} / \mathrm{L} \mathrm{KH}_{2} \mathrm{PO}_{4}, 1 \mathrm{~g} / \mathrm{L} \mathrm{K}_{2} \mathrm{HPO}_{4}, 1 \mathrm{~g} / \mathrm{L} \mathrm{NH}_{4} \mathrm{NO}_{3}$ and $0.05 \mathrm{~g} / \mathrm{L} \mathrm{FeCl}_{3}$ (Sigma-Aldrich). $1 \mathrm{ml}$ of petroleum-contaminated waste mud sample was added to $50 \mathrm{~mL}$ of $\mathrm{BH}$ (Sigma-Aldrich) medium containing $1 \%(\mathrm{v} / \mathrm{v})$ petroleum and $1 \%$ Triton X-100 (Merck) and incubated at $30{ }^{\circ} \mathrm{C}$ at $150 \mathrm{rpm}$ for 3 days (IKA ${ }^{\circ} \mathrm{KS} 4000 \mathrm{i}$, Germany). After incubation, $1 \mathrm{~mL}$ aliquot was transferred to fresh BH (SigmaAldrich) medium enriched with petroleum. Incubation was performed at $30^{\circ} \mathrm{C}$ at $150 \mathrm{rpm}$ for 3 days. The enrichment and incubation steps were further repeated twice.

\subsection{Isolation and identification of bacteria}

For the isolation of bacteria, $0.1 \mathrm{~mL}$ of enriched sample was inoculated onto nutrient agar and incubated at $30^{\circ} \mathrm{C}$ for $24 \mathrm{~h}$ [21]. The same procedure was repeated. Pure cultures of the isolated bacteria were obtained to compose three different bacterial consortia. While colony morphologies of isolated bacteria were examined macroscopically, microscopic examinations were performed by the Gram staining method. Phenotypic identification was carried out according to Bergey's Manual of Systematic Bacteriology [22]. For the taxonomic characterization of the isolated strains, 16S rRNA gene analysis was carried out by Refgen Gene Research and Biotechnology Limited Company, Ankara, Turkey. 533F GTG CCA GCM GCC GCG GTA A and 907R CCG TCA ATT CCT TTR AGT TT primers were used. Phylogenetic analysis was performed by MEGA-X Program.

\subsection{Preservation of pure cultures of isolated bacteria}

Pure cultures of Enterococcus casseliflavus, Klebsiella pneumoniae, Bacillus subtilis, Leuconostoc mesenteroides, Pannonibacter phragmitetus and Bacillus halotolerans were inoculated in Brain Heart Infusion (BHI) (Merck) with 10\% glycerol and incubated at $30^{\circ} \mathrm{C}$ at $150 \mathrm{rpm}$ for $24 \mathrm{~h}$ (IKA KS 4000i, Germany). All bacterial cultures were stored at $+4{ }^{\circ} \mathrm{C}$ and $-20^{\circ} \mathrm{C}$ in Hacettepe University Culture Collection Laboratory.

\subsection{Inoculum preparation}

The pure cultures of bacterial strains (Enterococcus casseliflavus, Klebsiella pneumoniae, Bacillus subtilis, Leuconostoc mesenteroides, Pannonibacter phragmitetus and Bacillus halotolerans) were inoculated in Nutrient Broth (NB) (Merck) and incubated at $150 \mathrm{rpm}$ at $30^{\circ} \mathrm{C}$ for overnight in a rotatory incubator (IKA ${ }^{\circ} \mathrm{KS} 4000 \mathrm{i}$, Germany). The individual bacterial strains were centrifuged at $4650 \mathrm{~g}$ for $10 \mathrm{~min}$ (Eppendorf 5810R). The cell pellets were washed with sterile $0.9 \% \mathrm{NaCl}(\mathrm{pH} 7)$ solution and centrifugated. These steps were further repeated twice. Bacterial suspensions were adjusted to 0.8 at a wavelength of $600 \mathrm{~nm}$ by UV spectrophotometer (Shimadzu-UV1700, Kyoto, Japan) [23].

\subsection{Petroleum biodegradation assays}

The petroleum biodegradation assay was carried out in $250 \mathrm{~mL}$ Erlenmeyer flasks containing $50 \mathrm{~mL} \mathrm{BH}$ (SigmaAldrich) medium. 1\% (v/v) Triton X-100 (Merck) was used as a surfactant source. In addition, $0.1 \%(\mathrm{w} / \mathrm{v})$ of glucose (Merck) and $0.1 \%(\mathrm{w} / \mathrm{v})$ of yeast extract (Merck) were used as additional carbon and nitrogen sources to increase the biodegradation of petroleum. The $\mathrm{pH}$ was adjusted to 7.0. All flasks were sterilized by autoclaving at $121^{\circ} \mathrm{C}$ for $15 \mathrm{~min}$. Following the cooling of the medium to $45^{\circ} \mathrm{C}, 1 \%$ $(\mathrm{v} / \mathrm{v})$ of petroleum which was sterilized by using a $0.22-$ $\mu \mathrm{m}$ syringe filter (Millipore, Sartorius) was added into the BH (Sigma-Aldrich) medium. Three different bacterial consortia (consortium 1, consortium 2 and consortium 3) were composed of bacterial strains which were adjusted to equal growth intensities. $2 \%$ of each consortium was inoculated into $\mathrm{BH}$ medium containing $1 \%$ of petroleum. Un-inoculated flasks were served as control. All flasks were incubated at $150 \mathrm{rpm}$ at $25^{\circ} \mathrm{C}$ for 7 days in the dark conditions (IKA $\left.{ }^{\circ} \mathrm{KS} 4000 \mathrm{i}, \mathrm{Germany}\right)$. The experiments were performed in triplicate. The method was carried out as described previously in Bilen Ozyurek and Bilkay [24]. 


\subsection{Screening of petroleum biodegradation potential of isolated bacteria by colorimetric analysis}

Petroleum biodegradation capacity of each bacterial strain was determined by colorimetric analysis [25]. The redox indicator solution was prepared by dissolving $1 \mathrm{~g}$ 2.6-dichloro phenol indophenol (DCPIP) (Fluka) into $1 \mathrm{~L}$ distilled water. All bacterial cultures grown in Bushnell Haas medium containing $1 \%$ petroleum and $1 \%$ redox indicator were centrifuged at $2325 \mathrm{~g}$ for $10 \mathrm{~min}$, and then pellet fractions were removed (Eppendorf 5810R). The absorbance of the blue redox indicator was determined at $600 \mathrm{~nm}$ in a spectrophotometer against a blank (Shimadzu UV-1700).

\subsection{Growth intensities of bacterial consortia}

The growth intensity of each bacterial consortium was determined by spectrophotometric analysis [8]. After the incubation period, the individual bacterial consortium was centrifuged at $2325 \mathrm{~g}$ for $10 \mathrm{~min}$ (Eppendorf 5810R). The cell pellets were washed with sterile distilled water. The cell suspensions were centrifuged at $8000 \mathrm{rpm}$ for $10 \mathrm{~min}$ (Eppendorf 5417C). These steps were further repeated twice. The absorbance of the bacterial consortia was determined at $600 \mathrm{~nm}$ in a spectrophotometer against a blank (Shimadzu UV-1700).

\subsection{Petroleum biodegradation of bacterial consortia by gravimetric analysis}

Petroleum biodegradation of each bacterial consortium was determined by gravimetric analysis [26]. Following the incubation of flasks, the residual petroleum was extracted with dichloromethane (DCM) $\left(\mathrm{CH}_{2} \mathrm{Cl}_{2}\right)$ (1:2) (SigmaAldrich). Then, the upper phase of solution was discarded. To evaporate DCM, Erlenmeyer flasks were placed in the water bath (Memmert, Schwabach, Germany) and left for half an hour at $90^{\circ} \mathrm{C}$. The biodegradation of petroleum was calculated as the difference between initial and final concentrations of petroleum $[24,26]$.

The removal of petroleum was determined, and then the specific degradation rate was calculated as follows:

$\mathrm{d}_{x} / x_{0} \cdot \mathrm{d}_{t}$

where $d_{x}$ is the change in concentration of the substrate and $x_{0}$ and $d_{t}$ indicate the substrate concentration and time interval, respectively.

\subsection{Degradation kinetics}

The degradation of petroleum fits the first-order reaction kinetics and can be calculated as follows:

$\ln C_{t}=\ln C_{0}-K_{t}$

where $C_{t}$ is the residual petroleum concentration at any time; $C_{0}$ indicates the initial petroleum concentration; $K$ denotes the rate constant for petroleum biodegradation $\left(\right.$ day $\left.^{-1}\right)$; and $t$ is the time (day). The half-life period of petroleum can be calculated as follows:

$t_{1 / 2}=\ln 2 / k$,

where $k$ is the biodegradation rate constant $\left(\right.$ day $\left.^{-1}\right)$ [27].

\subsection{Gas chromatography-mass spectrometry (GC- MS) analysis}

GC-MS analysis was performed to investigate the biodegradation of $n$-alkane fractions in petroleum by three different bacterial consortia. This analysis was carried out using TRB-1 GCMS-QP-2020 (Shimadzu, Tokyo, Japan), fitted with a capillary column (TRB-1 Teknokroma, Spain) (30 $\mathrm{m} \times 0.25 \mathrm{~m} \times$ i.d., $0.25 \mathrm{film}$ ) by the Petroleum Research Center at Middle East Technical University (METU) in Ankara, Turkey. The consortia were grown as described in Sect. 2.6. Residual petroleum was extracted with dichloromethane $\left(\mathrm{CH}_{2} \mathrm{Cl}_{2}\right)$ (Sigma-Aldrich) (1:2). The remaining moisture was removed by passing through the anhydrous $\mathrm{Na}_{2} \mathrm{SO}_{4}$ column. The carrier gas was helium at $1.5 \mathrm{~mL} / \mathrm{min}$; the injection temperature was $250^{\circ} \mathrm{C}$; the temperature program was set to $40^{\circ} \mathrm{C}$ (hold $5 \mathrm{~min}$ ) to $180^{\circ} \mathrm{C}$ at $8{ }^{\circ} \mathrm{C} /$ min and then to $320^{\circ} \mathrm{C}$ (hold $16 \mathrm{~min}$ ) at $10^{\circ} \mathrm{C} / \mathrm{min}$ [24].

\subsection{Statistical analysis}

All experiments were performed in triplicate. The mean and standard deviations of the three experiments were calculated. ANOVA test was performed to determine the significant differences in petroleum degradation efficiencies of three different consortia $(p \leq 0.05)$. SPSS ver. 18 software (Chicago, IL, USA) was used to carry out the statistical analysis [28]. The tests of normality were assessed using Kolmogorov-Smirnov and Shapiro-Wilk analyses. The Wilcoxon signed-rank test was used to compare particular pairs of bacterial consortia (consortium 1-consortium 2, consortium 1-consortium 3 and consortium 2-consortium 3). 
Table 1 Isolated and identified bacterial strains from petroleum-contaminated waste mud pit

\begin{tabular}{llll}
\hline $\begin{array}{l}\text { Number of } \\
\text { strains }\end{array}$ & Microorganisms & Reference strain & Similarity (\%) \\
\hline P1 & Bacillus subtilis & Bacillus subtilis MG847158.1 & 99 \\
P2 & Leuconostoc mesenteroides & Leuconostoc mesenteroides NR_074957.1 & 99 \\
P3 & Bacillus halotolerans & Bacillus halotolerans NR_115063.1 & 99 \\
P4 & Enterococcus casseliflavus & Enterococcus casseliflavus NR_119280.1 & 99 \\
P5 & Klebsiella pneumoniae & Klebsiella pneumoniae NR_117683.1 & 99 \\
P6 & Pannonibacter phragmitetus & Pannonibacter phragmitetus NR_028009.1 & 99 \\
\hline
\end{tabular}

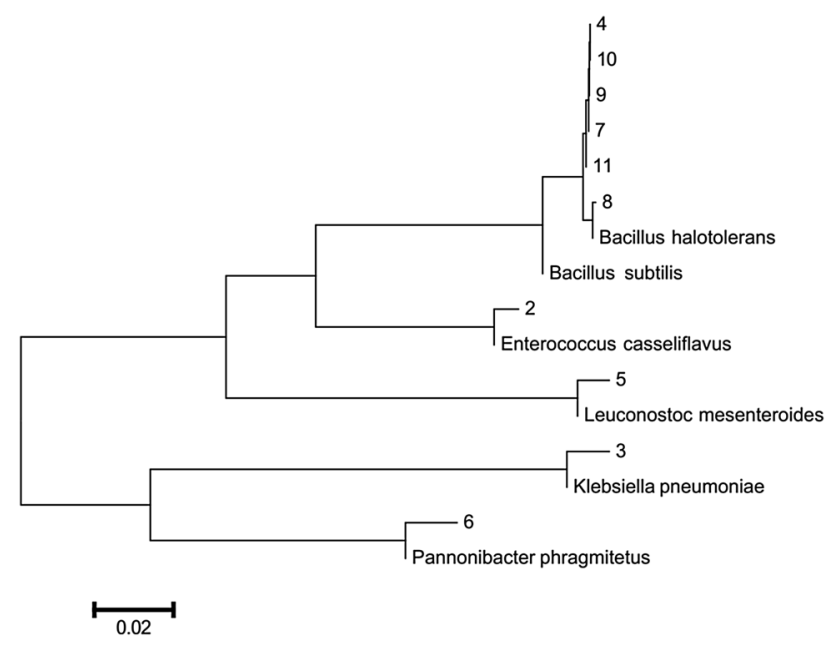

Fig. 1 Phylogenetic tree of the isolated bacterial strains

\section{Results and discussion}

\subsection{Identification of bacteria}

In this study, six different bacterial strains were isolated from petroleum-contaminated waste mud pit and identified as Bacillus subtilis, Leuconostoc mesenteroides, Bacillus halotolerans, Enterococcus casseliflavus, Klebsiella pneumoniae and Pannonibacter phragmitetus (Table 1). The phylogenetic tree of bacterial strains is shown in Fig. 1. Also, it was detected that $50 \%$ of the Gram-positive bacteria (Bacillus subtilis and Bacillus halotolerans) isolated from the petroleum-contaminated waste mud pit belonged to the genus Bacillus sp. Previous studies have shown that Bacillus sp. is dominant among microorganisms isolated from petroleum-contaminated soil and plays a role in the biodegradation of petroleum. The Bacillus genus is highly resistant to a high concentration of hydrocarbons due to its resistant endospore $[15,29]$. In addition to the dissemination and biodegradation capacity of Bacillus sp., Gram-negative bacteria also play an important role in the biodegradation of petroleum hydrocarbons [9]. Klebsiella pneumoniae and P. phragmitetus isolated from

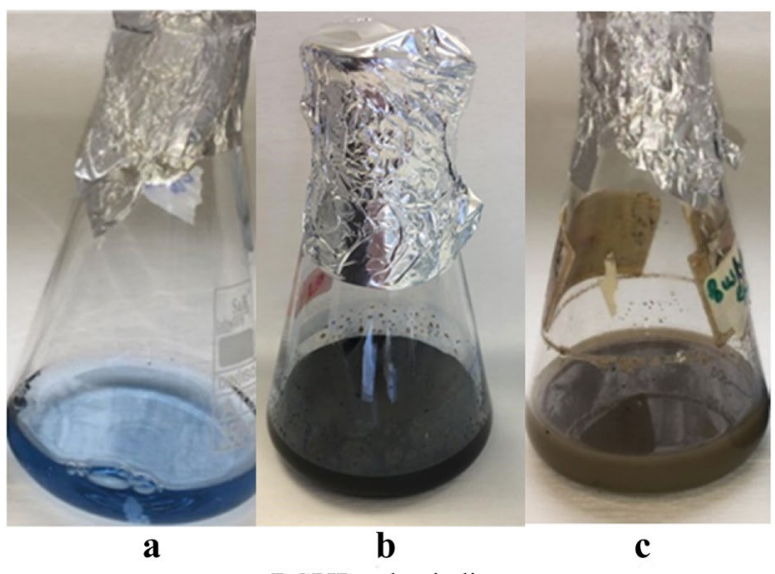

a: DCPIP redox indicator

b: DCPIP redox indicator + petroleum + inoculum (before incubation) c: DCPIP redox indicator + petroleum + inoculum (after incubation)

Fig. 2 Determination of color change in DCPIP redox indicator

petroleum-contaminated waste mud pit were known to be effective in the bioremediation process. Previous studies indicated that $K$. pneumoniae plays an active role in the biodegradation of petroleum [24] and P. phragmitetus is effective in the detoxification of heavy metals and PAHs [30].

\subsection{Evaluation of petroleum biodegradation of bacterial strains}

2.6-Dichloro phenol indophenol (DCPIP) redox indicator was used for pre-investigation of petroleum biodegradation capacities of Gram-positive and Gram-negative bacterial strains. The decolorization of the blue-colored redox indicator indicated that all bacterial strains had biodegradation capacity (Fig. 2). During the microbial oxidation process of petroleum, electrons are transferred to DCPIP as an electron acceptor. So, the color of DCPIP changed from blue (oxidized) to colorless (reduced). According to the studies in the literature, at the end of the incubation period the color change or decolorization of the blue redox indicator was interpreted as the petroleum 
biodegradation capabilities of the bacterial strains (Fig. 2) $[25,31,32]$.

\subsection{Evaluation of growth intensities and petroleum biodegradations of bacterial consortia}

The natural bioremediation process in the environment was carried out by the combined metabolic activities of mixed microbial populations [20,33]. Due to its highly complex structure, the biodegradation of petroleum hydrocarbons requires the cooperation of various microorganisms. In this context, three different bacterial consortia were composed such as consortium 1 (Gram-positive bacteria), consortium 2 (Gram-negative bacteria) and consortium 3 (mix cultures of Gram-positive and negative bacteria) (Table 2). These consortia were evaluated and compared in terms of growth intensities and petroleum biodegradation efficiencies by gravimetric analysis (Fig. 3). Although the growth intensity of consortium 1 was high, it had a low effect on the biodegradation of petroleum (48\%). So, consortium 1 was not as effective as consortia 2 and 3 in the biodegradation of petroleum. It is thought that Bacillus subtilis and Bacillus halotolerans were not metabolically compatible with each other. Due to limited carbon sources, antagonistic interactions and competition between Bacillus subtilis and Bacillus halotolerans strains composed of consortium 1 may lead to a decrease in the biodegradation of petroleum. However, a study in the literature showed that a consortium consisting of two biosurfactants producing bacteria $B$. pumilus $\mathrm{KS} 2$ and isolate R2 was selected as efficient crude oil degraders with their growth on crude oil [8]. ljah and Antai [29] reported that Bacillus sp. was the most effective isolate among all the crude oil utilizing bacteria isolated from crude oil-polluted soil. Bacillus genus which belongs to Gram-positive bacteria is known to be effective and successful in the biodegradation of petroleum hydrocarbons. In general, organic pollutants can be transformed through metabolic or enzymatic processes by microorganisms. This is based on two basic processes: growth and co-metabolism. Organic pollutant is used as a carbon and energy source in the first process. This process results in the complete biodegradation of organic pollutants. Co-metabolism is defined as the metabolism of organic pollutants where glucose is used as primary carbon and energy source. According to studies in the literature, it was estimated that consortium 1 can biodegrade petroleum by co-metabolism [9].

$77 \%$ of petroleum biodegradation was realized by consortium 2, despite low growth intensity. Thus, it can be clearly stated that this consortium was more effective in biodegradation of petroleum than consortium 1 (Fig. 3). This may be due to the fact that Gram-negative bacteria

Table 2 Bacterial content of three consortia

\begin{tabular}{ll}
\hline Bacterial consortia & Bacterial content \\
\hline Consortium 1 (Gram-positive strains) & Enterococcus casseliflavus, Bacillus subtilis, Leuconostoc mesenteroides, Bacillus halotolerans \\
Consortium 2 (Gram-negative strains) & Klebsiella pneumoniae, Pannonibacter phragmitetus \\
$\begin{array}{l}\text { Consortium } 3 \text { (Gram-positive and negative } \\
\text { strains) }\end{array}$ & $\begin{array}{c}\text { anterococcus casseliflavus, Bacillus subtilis, Leuconostoc mesenteroides, Bacillus halotoler- } \\
\text { aneumoniae, Pannonibacter phragmitetus }\end{array}$ \\
\hline
\end{tabular}

Fig. 3 Petroleum biodegradation and bacterial growth of bacterial consortia. *Growths of bacterial consortia were carried out at $25^{\circ} \mathrm{C}$ and 150 rpm for 7 days. Results are the average of three measurements. Standard deviations are shown on the graph. Bacterial growths were diluted to $1 / 10$

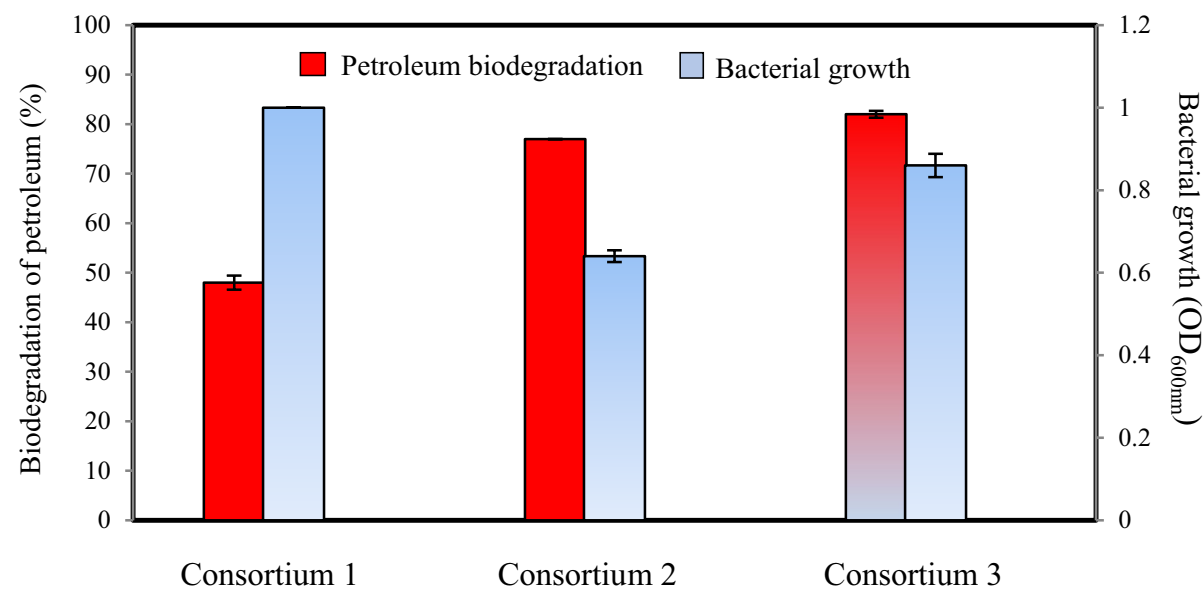

SN Applied Sciences 
are more effective in the biodegradation of petroleum than Gram-positive bacteria because of being less sensitive to the toxic effects of hydrocarbons. Varjani and Upasani [34] reported that the consortium "HUBC," consisting of six different Gram-negative bacterial strains isolated from crude oil-contaminated soil, was found to be effective in the utilization of petroleum components. Sphingomonas koreensis ASU-06 strain utilized naphthalene, phenanthrene, anthracene and pyrene as a sole carbon source by its dioxygenase activity [35]. In addition, microbial enzymes of Gram-negative bacterial strains such as K. pneumoniae and P. phragmitetus play an active role in petroleum biodegradation. The biodegradation of an organic pollutant is generally dependent on the concentration of the pollutant and the quantities of microbial enzymes. The metabolism of the pollutant varies with the wide functional groups of specific enzymes, their affinity to pollutants and their availability [9]. Genes encoding the mono- and dioxygenase enzymes that play a role in the biodegradation of PAHs and aliphatic hydrocarbons have been found to be highly conserved in Gram-negative bacteria [35].

Consortium 3 achieved more than $80 \%$ of petroleum biodegradation with its high growth intensity (Fig. 3). The synergistic interaction between Gram-positive and Gramnegative bacterial strains allows complete biodegradation of organic pollutants. In recent years, microbial consortium applications in petroleum biodegradation have been carried out all over the world [36, 37]. Moneke and Nwangwu [38] evaluated Pseudomonas sp., Bacillus sp., Klebsiella sp. and Proteus sp. strains to utilize kerosene, engine oil and automotive oil as the sole carbon source both as a single and as a mixed culture. Therefore, it was clearly demonstrated that bacterial mix culture had the most appreciable growth on hydrocarbon sources [38]. Prakash et al. [39] showed that mixed bacterial culture of Bacillus sp. APHP6, Pseudomonas sp. APHP9 and APBP1 and Micrococcus sp. APIO4 achieved the maximum benzene and diesel degradation. Wanapaisan et al. [40] reported that the consortium formed by Mycobacterium spp. PO1 and PO2, Novosphingobium pentaromativorans PY1, Ochrobactrum sp. PW1 and Bacillus sp. FW1 was successful in pyrene biodegradation. This cooperative interaction between bacterial strains led to enhanced pyrene biodegradation in the consortium [40]. Microbial consortium provides metabolic complementarity. The metabolite, which is produced by a microorganism as an incomplete degradation product, can be used as a carbon source by another microorganism [33]. The biodegradation of petroleum hydrocarbons by microbial communities depends on the composition of the consortium and the ability to use hydrocarbons $[4,8]$.

The kinetics of biodegradation processes depend on the rate and improvement in the effective degradation of petroleum [41]. According to biodegradation efficiencies of consortia, the specific degradation rates of consortium 1, consortium 2 and consortium 3 were $0.068,0.110$ and 0.117 , per day, respectively. The abiotic loss was negligible because of $1.5 \%$ reduction observed in petroleum. In the abiotic control, specific degradation rate was calculated $0.002 \mathrm{day}^{-1}$ for petroleum. The degradation rate constant and half-life period of consortia were determined according to the first-order kinetics model equation. Thus, rate constant was the highest in consortium 3 (1.713 day ${ }^{-1}$, $\left.t_{1 / 2}=0.404\right)$ followed by consortium 2 (1.469 day $^{-1}$, $\left.t_{1 / 2}=0.463\right)$ and consortium 1 ( 0.653 day $\left.^{-1}, t_{1 / 2}=1.06\right)$ in a decreasing order. Kachieng'a and Momba [41] reported that the highest rate constant of 1.11 day $^{-1}$ was observed for a consortium consisting of three different protozoa. In a similar study, the reaction rate constants of Pseudomonas pseudoalcaligenes, Bacillus megaterium and Xanthobacter autotrophicus were $0.0189,0.0324$ and 0.0324 day $^{-1}$, respectively. According to the reaction rates, Xanthobacter autotrophicus was the most effective bacteria in the degradation of petroleum oil sludge [42]. Considering the results in the literature, it was clearly stated that the halflife period was low with a high degradation rate constant in consortium 3, which had the highest biodegradation rate.

ANOVA test results revealed that there were significant differences between petroleum degradation efficiencies of three different consortia $(p \leq 0.05)$. The results of the Kolmogorov-Smirnov and Shapiro-Wilk analyses revealed that the petroleum degradation efficiencies of three different consortia were not normally distributed. The Wilcoxon signed-rank test also showed that there was a significant difference between two pairs of consortia (consortium 1-consortium 2, consortium 1-consortium 3 and consortium 2-consortium 3).

\subsection{Biodegradation of $\boldsymbol{n}$-alkane fractions in petroleum}

The microbial degradation of petroleum should be supported by analytical methods defined for the major and minor components of the petroleum [14]. In this manner, each hydrocarbon ( $n$-alkane) constituting the content of petroleum has been examined by GC-MS analysis (Table 3). Similar to the gravimetric analysis, GC-MS analysis showed that consortium 1 had a lower effect on biodegradation of $C_{10}-C_{20} n$-alkanes than consortia 2 and 3. Consortium 1 was not effective on $n$-alkanes in the range of $C_{15}-C_{21}$, while the short-chain $n$-alkanes in the $\mathrm{C}_{10}-\mathrm{C}_{14}$ range were biodegraded from 11 to $49 \%$. It was also shown that longchain $n$-alkanes ranging from $C_{23}$ to $C_{32}$ were biodegraded at a range of $35-58 \%$ (Fig. 4). Although the Bacillus species are effective in petroleum biodegradation and resistant to 
Table 3 Gas chromatographymass spectrometry analysis of petroleum

\begin{tabular}{|c|c|c|c|c|}
\hline \multirow[t]{2}{*}{ Alkane fractions of petroleum } & \multirow[t]{2}{*}{ Initial day } & \multicolumn{3}{|c|}{ 7th day of incubation period } \\
\hline & & Consortium 1 & Consortium 2 & Consortium 3 \\
\hline$n$-Decane (C10), ppm & 27.91 & 14.83 & 9.27 & 8.56 \\
\hline$n$-Undecane (C11), ppm & 22.96 & 12.87 & 5.93 & 4.91 \\
\hline$n$-Dodecane (C12), ppm & 35.99 & 26.30 & 15.00 & 13.02 \\
\hline$n$-Tridecane (C13), ppm & 25.27 & 20.68 & 9.25 & 6.15 \\
\hline n-Tetradecane (C14), ppm & 31.99 & 28.62 & 16.68 & 13.33 \\
\hline n-Pentadecane (C15), ppm & 25.81 & 25.81 & 16.88 & 13.63 \\
\hline n-Hexadecane (C16), ppm & 23.26 & 23.26 & 14.62 & 11.82 \\
\hline$n$-Heptadecane (C17), ppm & 27.13 & 27.13 & 17.16 & 14.33 \\
\hline n-Octadecane (C18), ppm & 12.41 & 12.41 & 12.14 & 10.00 \\
\hline n-Nonadecane (C19), ppm & 19.51 & 19.51 & 14.07 & 12.15 \\
\hline$n$-Eicosane (C20), ppm & 15.54 & 15.54 & 13.92 & 12.30 \\
\hline n-Heneicosane (C21), ppm & 15.82 & 15.82 & 14.51 & 12.78 \\
\hline n-Docosane (C22), ppm & 20.96 & 18.10 & 11.62 & 9.99 \\
\hline$n$-Tricosane (C23), ppm & 27.65 & 17.97 & 12.12 & 10.12 \\
\hline$n$-Tetracosane (C24, ppm & 31.83 & 14.51 & 10.55 & 8.41 \\
\hline n-Pentacosane (C25), ppm & 27.43 & 14.14 & 10.96 & 8.46 \\
\hline n-Hexacosane (C26), ppm & 21.65 & 10.04 & 7.77 & 6.51 \\
\hline n-Heptacosane (C27), ppm & 13.49 & 6.51 & 5.09 & 4.23 \\
\hline n-Octacosane (C28), ppm & 9.77 & 4.69 & 3.74 & 3.18 \\
\hline n-Nonacosane (C29), ppm & 7.46 & 3.66 & 2.91 & 2.53 \\
\hline$n$-Triacontane (C30), ppm & 5.44 & 2.29 & 1.85 & 1.86 \\
\hline$n$-Hentriacontane (C31), ppm & 4.38 & 2.35 & 1.60 & 1.40 \\
\hline$n$-Dotriacontane (C32), ppm & 4.32 & 1.86 & 1.57 & 1.41 \\
\hline$n$-Tritriacontane (C33), ppm & $<2.59$ & 1.84 & 1.32 & 1.32 \\
\hline$n$-Tetratriacontane (C34), ppm & $<2.73$ & $<2.73$ & $<2.73$ & $<2.73$ \\
\hline n-Pentatriacontane (C35), ppm & $<3.77$ & $<3.77$ & $<3.77$ & $<3.77$ \\
\hline$n$-Hexatriacontane (C36), ppm & $<2.81$ & $<2.81$ & $<2.81$ & $<2.81$ \\
\hline n-Octatriacontane (C38), ppm & $<5.73$ & $<5.73$ & $<5.73$ & $<5.73$ \\
\hline n-Tetracontane (C40), ppm & $<6.93$ & $<6.93$ & $<6.93$ & $<6.93$ \\
\hline
\end{tabular}

ppm parts-per million
Fig. 4 Biodegradation of different $n$-alkane fractions of petroleum by three bacterial consortia

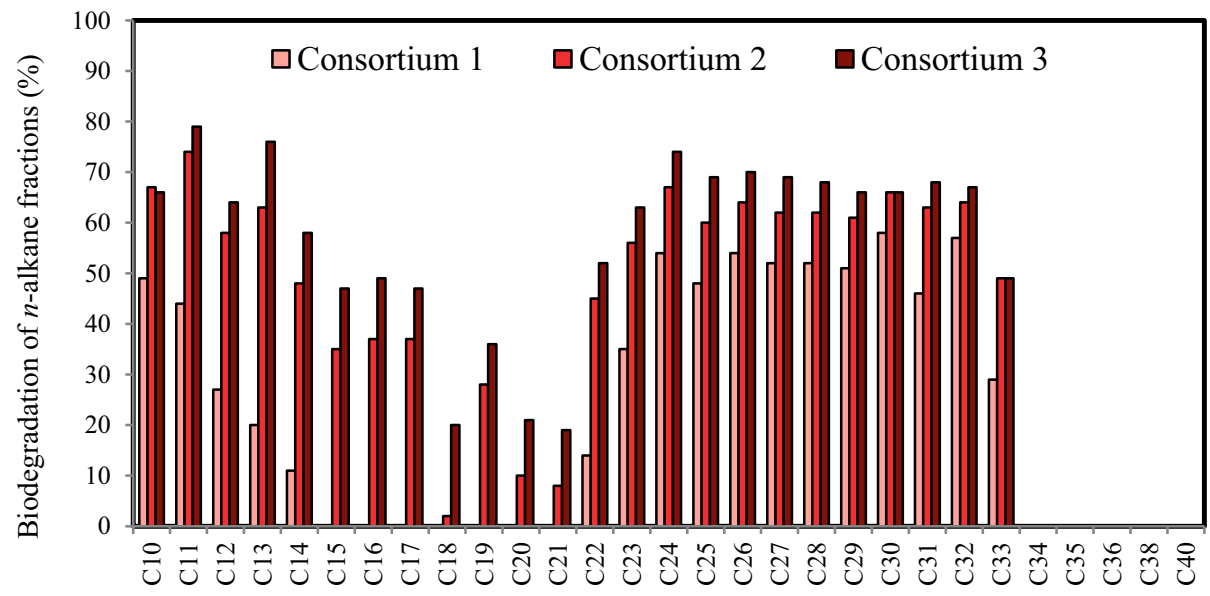

adverse environmental conditions, no synergistic effect was observed in consortium 1 in terms of biodegradation of $n$-alkane fractions in petroleum. The use of Gram-positive bacterial strains, including Bacillus subtilis and Bacillus halotolerans, did not have a significant effect on petroleum biodegradation compared to consortium 2 and consortium 
3. However, Bacillus sp. L30 strain was the most effective bacterium in degrading $n$-alkane $\left(C_{10}-C_{27}\right)$ from diesel after 7 days of incubation [43]. Parthipan et al. [44] stated that more than $97 \%$ of the $n$-alkanes ranged from $C_{15}$ to $C_{19}$ were utilized by the $B$. subtilis A1. Similar studies reported that Bacillus sp. strains were effective in the biodegradation of $n$-alkane fractions of petroleum hydrocarbons $[8,16]$. This can be due to the difference in the concentration and type of petroleum used in the studies, the method used to determine the petroleum biodegradation or incubation period. Furthermore, toxic intermediate metabolites are formed as a result of co-metabolism [14]. Hydrocarbon toxicity depends not only on its physical properties but also on the specific response of the cells. The cellular response of each bacterial strain is different, and the resistance of Gram-positive bacterial strains to toxic organic compounds varies from one strain to another. Gram-positive bacteria are getting more exposed to the toxic effects of these compounds due to the absence of additional barriers such as the outer membrane of Gram-negative bacteria [45]. This leads to a decrease in the degradation of petroleum hydrocarbons.

Consortium 2 biodegraded short-chain $n$-alkanes in the range of $\mathrm{C}_{10}-\mathrm{C}_{14}$ at $48-74 \%$ and longer-chain $n$-alkanes in the range of $C_{23}-C_{32}$ at $56-67 \%$. This consortium was more effective on the biodegradation of $n$-alkanes than consortium 1 (Fig. 4). It has also been determined in previous studies that Klebsiella pneumoniae and Pannonibacter phragmitetus, which formed the consortium 2, were effective in the biodegradation of various organic environmental pollutants. In a previous study, it was shown that $K$. pneumoniae had an effect on short-, medium- and longchain $n$-alkanes via enzyme systems and can be used in bioremediation studies [24]. However, You et al. [28] clearly showed that $K$. pneumoniae only biodegraded hydrocarbons in the range of $C_{10}-C_{14}$ in diesel. Zhou et al. [30] reported that Pannonibacter phragmitetus was resistant to extreme environmental conditions such as hot springs, high alkaline conditions and high salt concentration and plays a role in the detoxification of PAHs and heavy metal chrome reduction in these environmental conditions. Acinetobacter sp. has been shown to metabolize hydrocarbons in the range of $C_{10}-C_{40}$ [4]. It has been reported in the literature that Gram-negative bacteria are generally more successful in the biodegradation of petroleum hydrocarbons, which is parallel with our findings. Petroleum biodegradation abilities of Gram-negative bacterial strains can be explained by plasmid or chromosomal originated genes that play a role in hydrocarbon biodegradation and porins located in the cell wall $[45,46]$.

Consortium 3 was found to be the most effective mixed culture in the biodegradation of short-, medium- and long-chain $n$-alkanes in petroleum. Short-chain and medium-chain $n$-alkanes were biodegraded at $58-79 \%$ and $20-50 \%$, respectively, by consortium 3 . This consortium has also 63-74\% biodegradation efficiency on longchain $n$-alkanes in the range of $C_{23}-C_{32}$ (Fig. 4). Strikingly, long-chain $n$-alkanes were biodegraded as effectively as short-chain $n$-alkanes by consortium 3 . The metabolic cooperation and synergistic effect between Gram-positive and Gram-negative bacterial strains had a positive effect on the biodegradation of petroleum processes. In a similar study, it was determined that consortia 1 and 2, which were formed by Gram-positive and Gram-negative bacteria, increased the biodegradation of medium- and long-chain aliphatic compounds in the soil [16]. Cerqueira et al. [33] reported that bacterial consortia composed of Stenotrophomonas acidaminiphila, Bacillus megaterium, Bacillus cibi, Pseudomonas aeruginosa and Bacillus cereus had high degradation capacity of oily sludge (reducing $90.7 \%$ of the aliphatic fraction and $51.8 \%$ of the aromatic fraction).

The results in this study clearly pointed out that the consortium 3, composed of Gram-positive and Gram-negative bacterial strains, was more effective in the biodegradation of the aliphatic fractions (short- and long-chain $n$-alkanes) of petroleum in a short incubation period when compared with other consortia.

\section{Conclusion}

The petroleum biodegradation efficiencies of three different consortia isolated from petroleum-contaminated waste mud pit have been examined. It was found out that consortium 3 was more effective in the biodegradation of petroleum than consortium 1 and consortium 2 . It was also clearly emphasized that consortium 3 was successful in the biodegradation of petroleum in a shorter incubation period (7 days) compared to similar consortia in the literature. Considering all data, the use of consortium 3 will make a significant contribution to further bioremediation studies.

Acknowledgements This work is supported by the Hacettepe University Scientific Research Projects Coordination Unit (Project Number: FHD-2017-15077).

\section{Compliance with ethical standards}

Conflict of interest The authors declare that they have no conflict of interest. 


\section{Appendix: Statistical analysis}

See Tables 4, 5 and 6.

Table 4 ANOVA test analysis

Table 5 Kolmogorov-Smirnov and Shapiro-Wilk analyses
Table 6 Wilcoxon signed-rank test

Consortium 1-

Consortium 2

\begin{tabular}{lc}
\hline$Z$ & $-4.291^{\mathrm{b}}$ \\
Asymp. Sig. (two-tailed) & 0.000 \\
\hline & Consortium 1- \\
& Consortium 3 \\
\hline$Z$ & $-4.288^{\mathrm{b}}$ \\
Asymp. Sig. (two-tailed) & 0.000 \\
\hline & Consortium 2- \\
\hline$Z$ & Consortium 3 \\
\hline Asymp. Sig. (two-tailed) & $-4.080^{\mathrm{b}}$ \\
\hline
\end{tabular}

${ }^{\mathrm{b}}$ Based on positive ranks

\begin{tabular}{llllllll}
\hline & \multicolumn{2}{l}{ Kolmogorov-Smirnov $^{\mathrm{a}}$} & & & \multicolumn{2}{l}{ Shapiro-Wilk } \\
\cline { 2 - 3 } & Statistic & $d f$ & Sig. & & Statistic & $d f$ & Sig. \\
\hline Tests of normality & & & & & & & \\
Consortium 1 & 0.260 & 29 & 0.000 & & 0.799 & 29 & 0.000 \\
Consortium 2 & 0.199 & 29 & 0.005 & & 0.832 & 29 & 0.000 \\
Consortium 3 & 0.206 & 29 & 0.003 & & 0.836 & 29 & 0.000 \\
\hline
\end{tabular}

${ }^{a}$ Lilliefors significance correction 


\section{References}

1. El-Borai AM, Eltayeb KM, Mostafa AR, El-Assar SA (2016) Biodegradation of industrial oil-polluted waste water in Egypt by bacterial consortium immobilized in 28 different types of carriers. Pol J Environ Stud 25:1901-1909

2. Olajire AA, Alade AO, Adeniyi AA, Olabemiwo OM (2007) Distribution of polycyclic aromatic hydrocarbons in surface soils and water from the vicinity of Agbabu bitumen field of Southwesthern Nigeris. J Environ Sci Health, Part A 42:1043-1049

3. Olajire AA, Olujobade IM, Olabemiwo OM (2008) n-Alkanes distributions in soil and water samples collected near Agbabu bitumen field of southwestern Nigeria. Int J Environ Stud 65:769-779

4. Olajire AA, Essien JP (2014) Aerobic degradation of petroleum components by microbial consortia. J Pet Environ Biotechnol 5:3-22

5. Pathak $H$, Vashistha A, Jain PK, Nagmani A, Jaroli DP, Lowry M (2010) Physicochemical properties of petroleum contaminated soil collected from coastal areas of Mumbai. Asian J Exp Sci 24:175-178

6. Xu N, Bao M, Sun P, Li Y (2013) Study on bioadsorption and biodegradation of petroleum hydrocarbons by a microbial consortium. Bioresour Technol 149:22-30

7. Bento FM, Camargo FAO, Okeke BC, Frankenberger WT (2005) Comparative bioremediation of soils contaminated with diesel oil by natural attenuation, biostimulation and bioaugmentation. Bioresour Technol 96:1049-1055

8. Patowary K, Patowary R, Kalita MC, Deka S (2016) Development of an efficient bacterial consortium for the potential remediation of hydrocarbons from contaminated sites. Front Microbiol $7: 1-14$

9. Joutey NT, Bahafid W, Sayel H, Ghachtouli NE (2013) Biodegradation: involved microorganisms and genetically engineered microorganisms. In: Chamy R, Rozenkranz F (eds) Biodegradation-life of science. Intech, London, pp 289-320

10. Ogilvie LA, Hirsch PR (2012) Microbial ecology theory: current perspectives. Caister Academic Press, Norfolk

11. Palanisamy N, Ramya J, Kumar S, Vasanthi NS, Chandran P (2014) Diesel biodegradation capacities of indigenous bacterial species isolated from diesel contaminated soil. J Environ Health Sci Eng 12:1-8

12. Wang H, Xu R, Li F, Qiao J, Zhang B (2010) Efficient degradation of lube oil by a mixed bacterial consortium. J Environ Sci 22:381-388

13. Marinescu M, Dumitru M, Lacatusu A (2009) Biodegradation of petroleum hydrocarbons in artificial polluted soil. Res J Agric Sci 41:157-162

14. Vinas M, Grifoll M, Sabate J, Solanas AM (2002) Biodegradation of crude oil by three microbial consortia of different origins and metabolic capabilities. J Ind Microbiol Biotechnol 28:252-260

15. Sinha S, Chattopadhyay P, Pan I, Chatterjee S, Chandal P, Das K, Sukanta K, Bandyopadhyay SD (2009) Microbial transformation of xenobiotics for environmental bioremediation. Afr J Biotechnol 8:6016-6027

16. Ghazali FM, Abdul Rahman RNZ, Salleh AB, Basri M (2004) Biodegradation of hydrocarbons in soil by microbial consortium. Int Biodeterior Biodegrad 54:61-67

17. Venosa AD, Zhu X (2003) Biodegradation of crude oil contaminating marine shorelines and freshwater wetlands. Spill Sci Technol Bull 8:163-178

18. Dasgupta D, Ghosh R, Sengupta TK (2013) Biofilm-mediated enhanced crude oil degradation by newly isolated Pseudomonas species. ISRN Biotechnol 2013:1-13
19. Atlas RM, Bartha R (1998) Fundamentals and applications' in microbial ecology, 4th edn. Benjamin-Cummings, Menlo-Park, pp 523-530

20. Janbandhu A, Fulekar MH (2011) Biodegradation of phenanthrene using adapted microbial consortium isolated from petrochemical contaminated environment. J Hazard Mater 187:333-340

21. Eraydin Erdogan E, Sahin F, Karaca A (2012) Determination of petroleum degrading bacteria isolated from crude oil contaminated soil in Turkey. Afr J Biotechnol 11:4853-4859

22. Mohapatra PK (2008) Textbook of environmental microbiology. I.K. International Publishing House Pvt. Ltd., New Delhi

23. Lily MK, Bahuguna A, Dangwal K, Garg V (2009) Degradation of Benzo[a] pyrene by a novel strain Bacillus subtilis BMT4i (MTCC9447). Braz J Microbiol 40:884-892

24. Bilen Ozyurek S, Seyis Bilkay I (2018) Biodegradation of petroleum by Klebsiella pneumoniae isolated from drilling fluid. Int J Environ Sci Technol 15:2107-2116

25. Selvakumar S, Sekar P, Rajakumar S, Ayyasamy PM (2014) Rapid screening of crude oil degrading bacteria isolated from oil contaminated areas. Scitech J 1:24-27

26. Ganesh A, Lin J (2009) Diesel degradation and biosurfactant production by gram positive isolates. Afr J Biotechnol 8:5847-5854

27. Al-Hawash A, Alkooranee JT, Abbood HA, Zhang J, Sun J, Zhang $X$, Ma F (2018) Isolation and characterization of two-crude oildegrading fungi strains from Rumila oil field. Biotechnol Rep 17:104-109

28. You Z, Xu H, Zhang S, Kim H, Chiang P-C, Yun W, Zhang L, He $M$ (2018) Comparison of petroleum hydrocarbons degradation by Klebsiella pneumonia and Pseudomonas aeruginosa. Appl Sci $8: 1-19$

29. Ijah UJJ, Antai SP (2003) Removal of Nigerian light crude oil in soil over a 12-month period. Int Biodeterior Biodegrad 51:93-99

30. Zhou Y, Jiang T, Hu S, Wang M, Ming D, Chen S (2017) Genomic insights of Pannonibacter phragmitetus strain 31801 isolated from a patient with a liver abscess. Microbiologyopen. https:// doi.org/10.1002/mbo3.515:1-14

31. Nakamura FM, Germano MG, Tsai SM (2014) Capacity of aromatic compound degradation by bacteria from Amazon Dark Earth. Diversity 6:339-353

32. Prasthyusha K, Jagan Mohan YSYV, Sridevi S, Sandeep BV (2016) Isolation and characterization of petroleum hydrocarbon degrading indigenious bacteria from contaminated sites of Visakhapatnam. Int J Adv Res 4:357-362

33. Cerqueira VS, Hollanbach EB, Maboni F, Vainstein MH, Camargo FA, Peralba MCR, Bento FM (2011) Biodegradation potential of oily sludge by pure and mixed bacterial cultures. Bioresour Technol 102:11003-11010

34. Varjani SJ, Upasani VN (2013) Comparative studies on bacterial consortia for hydrocarbon degradation. Int J Innov Res Sci Eng Technol 2:5377-5383

35. Hesham AEL, Mawad AMM, Mostafa YM, Shoreit A (2014) Biodegradation ability and catabolic genes of petroleum-degrading Sphingomonas koreensis strain ASU-06 isolated from Egyptian oily soil. Biomed Res Int 2014:1-10

36. Rahman KSM, Thahira-Rahman J, Lakshmanaperumalsamy $P_{1}$ Banat IM (2002) Towards efficient crude oil biodegradation by a mixed bacterial consortium. Bioresour Technol 85:257-261

37. Plaza GA, Lukasik K, Wypych J, Nalecz-Jawecki Berry C, Brigmon RL (2008) Biodegradation of crude oil and distillation products by biosurfactant producing bacteria. Pol J Environ Stud 17:87-94

38. Moneke A, Nwangwu C (2011) Studies on the bioutilization of some petroleum hydrocarbons by single and mixed cultures of some bacterial species. Afr J Microbiol Res 5:1457-1466 
39. Prakash A, Bisht S, Singh J, Teotia P, Kela R, Kumar V (2014) Biodegradation potential of petroleum hydrocarbons by bacteria and mixed bacterial consortium isolated from contaminated sites. Turk J Eng Environ Sci 38:41-50

40. Wanapaisan P, Laothamteep N, Vejarano F, Chakraborty J, Shintani M, Muangchinda C, Morita T, Suzuki-Minakuchi C, Inoue K, Nojiri H, Pinyakong (2018) Synergistic degradation of pyrene by five culturable bacteria in a mangrove sediment-derived bacterial consortium. J Hazard Mater 342:561-570

41. Kachieng'a L, Momba MNB (2017) Kinetics of petroleum oil biodegradation by consortium of three protozoan isolates (Aspidisca sp., Trachelophyllum sp. and Peranema sp.). Biotechnol Rep 15:125-131

42. Yudano B, Said M, Sabaruddin Napoleon A, Fanani Z (2011) Kinetics approach of biodegradation of petroleum contaminated soil by using indigenous isolated bacteria. J Trop Soils 16:33-38

43. Lima SD, Oliveira AF, Golin R, Lopes VCP, Caixeta DS, Lima ZM, Morais EB (2019) Isolation and characterization of hydrocarbons-degrading bacteria from gas station leakingcontaminated groundwater in the Southern Amazon, Brazil. Braz J Biol. https://doi.org/10.1590/1519-6984.208611

44. Parthipan P, Preetham E, Machuca LL, Rahman PKSM, Murugan K, Rajasekar (2017) Biosurfactant and degradative enzymes mediated crude oil degradation by bacterium Bacillus subtilis A1. Front Microbiol 8:1-14

45. Lăzăroaie MM (2010) Multiple responses of Gram-positive and Gram-negative bacteria to mixture of hydrocarbons. Braz J Microbiol 41:649-667

46. Akpe AR, Ekundayo AO, Aigere SP, Okwu GI (2015) Bacterial degradation of petroleum hydrocarbons in crude oil polluted soil amended with cassava peels. Am J Res Commun 3:99-188

Publisher's Note Springer Nature remains neutral with regard to jurisdictional claims in published maps and institutional affiliations. 